\title{
Low-Protein Diet during Lactation and Maternal Metabolism in Rats
}

\author{
Vera L. Moretto, ${ }^{1}$ Marcia O. Ballen, ${ }^{1}$ Talita S. S. Gonçalves, ${ }^{2}$ Nair H. Kawashita, ${ }^{3}$ \\ Luiz F. Stoppiglia, ${ }^{4}$ Roberto V. Veloso, ${ }^{4}$ Márcia Q. Latorraca, ${ }^{4}$ Maria Salete F. Martins, ${ }^{4}$ \\ and Maria Helena G. Gomes-da-Silva ${ }^{4}$ \\ ${ }^{1}$ Curso de Pós Graduação em Ciências da Saúde, Faculdade de Ciências Médicas, Universidade Federal de Mato Grosso (UFMT), \\ 78060-900 Cuiabá, MT, Brazil \\ ${ }^{2}$ Programa de Iniciação Científica, Fundação de Apoio à Pesquisa do Estado de Mato Grosso (FAPEMAT), 78050-970 Cuiabá, \\ MT, Brazil \\ ${ }^{3}$ Departamento de Química, ICET, UFMT, 78060-900 Cuiabá, MT, Brazil \\ ${ }^{4}$ Departamento de Alimentos e Nutrição, Faculdade de Nutrição (FANUT), Universidade Federal de Mato Grosso (UFMT), \\ Avenida Fernando Correa da Costa, 2367. Bairro Boa Esperança, 78060-900 Cuiabá, MT, Brazil
}

Correspondence should be addressed to Maria Helena G. Gomes-da-Silva, marihele@ufmt.br

Received 2 September 2010; Accepted 12 October 2010

Academic Editor: K. Yang

Copyright ( $\odot 2011$ Vera L. Moretto et al. This is an open access article distributed under the Creative Commons Attribution License, which permits unrestricted use, distribution, and reproduction in any medium, provided the original work is properly cited.

Some metabolic alterations were evaluated in Wistar rats which received control or low-protein (17\%; 6\%) diets, from the pregnancy until the end of lactation: control non-lactating $(\mathrm{CNL})$, lactating $(\mathrm{CL})$, low-protein non-lactating (LPNL) and lactating (LPL) groups. Despite the increased food intake by LPL dams, both LP groups reduced protein intake and final body mass was lower in LPL. Higher serum glucose occurred in both LP groups. Lactation induced lower insulin and glucagon levels, but these were reduced by LP diet. Prolactin levels rose in lactating, but were impaired in LPL, followed by losses of mammary gland (MAG) mass and, a fall in serum leptin in lactating dams. Lipid content also reduced in MAG and gonadal white adipose tissue of lactating and, in LPL, contributed to a decreased daily milk production, and consequent impairment of body mass gain by LPL pups. Liver mass, lipid content and ATP-citrate enzyme activity were increased by lactation, but malic enzyme and lipid: glycogen ratio elevated only in LPL. Conclusion. LP diet reduced the development of MAG and prolactin secretion which compromised milk production and pups growth. Moreover, this diet enhanced the store of lipid to glycogen ratio and suggests a higher risk of fatty liver development.

\section{Introduction}

Lipids are the major source of energy for most tissues during periods of negative energy balance, but in some circumstances they can have pathological effects [1]. Triacylglycerol (TAG) is stored in various adipose tissue depots of body, but if blood nonesterified fatty acid (NEFA) levels are elevated for prolonged periods, as it may occur during lactation or obesity, TAG can accumulate in other tissues including liver and muscle cells and can have pathological consequences such as the development of ketosis [2], type 2 diabetes [3], or nonalcoholic fatty liver [4]. During lactation, liver, adipose tissue, and mammary gland (MAG) are the major sites of fatty acid metabolism and are able to synthesize the in vivo fatty acids de novo and esterify them to TAG [1].

Lactation comprises a catabolic mode of adipose tissue metabolism, with markedly reduced fatty acid synthesis/esterification and low-lipoprotein lipase activity $[5,6]$. By contrast, lipogenesis is increased in MAG, ensuring a preferential uptake of TAG precursors for milk fat production [7]. In this phase, MAG becomes the most active site of lipogenesis, exceeding by 4 -fold the liver [8].

The liver has a more complex role in lipid metabolism than adipose or mammary tissue, taken up NEFA from 
the blood and either oxidizing them to $\mathrm{CO}_{2}$ or ketones (ketoacetate and $\beta$-hydroxybutyrate), which are released into the blood for use elsewhere in the body, or esterifying fatty acids to TAG and phospholipids, which are then secreted into the blood as lipoproteins including very low density lipoproteins (VLDL). In lactation, several mechanisms promote the oxidation of fatty acids in the liver $[2,6]$, which are related to a fall in serum insulin accompanied by a rise in glucagon and also in NEFA [9]. Despite the fall in the serum insulin to glucagon ratio and other mechanisms that operate to promote fatty acid oxidation, fatty acid esterification is also increased in the liver during lactation. This is primarily due to the substantial increase in NEFA uptake but, in addition, the activities of some esterification enzymes are also increased [10]. The physiological purpose of the TAG accumulation in the liver is not clear. It may be a default of a system in which NEFA uptake by the liver is determined by supply rather than need, reflecting the role of the liver in regulating the nutrient composition of the blood $[11,12]$.

According to Choi et al. [13], the intrauterine growth retardation caused by protein deficiency of the mother plays an important role in the adult life development of "fatty liver" or fat accumulation within liver. It also increased risk of adult metabolic syndrome, clustering cardiovascular risk factors such as diabetes, hypertension, dyslipidemia, and obesity [14]. This liver lipid accumulation is a feature seen in protein-calorie malnutrition such as kwashiorkor [4].

In our laboratory, we observed low-protein dams on the 14th day of lactation lower serum insulin levels and this study showed that the maternal metabolic adaptation to hypoinsulinaemia resulted in higher insulin sensitivity, enhanced carcass fat deposition, hyperleptinaemia, and hypophagia [15]. The aim of the present study was to evaluate some metabolic alterations on maternal metabolism in low-protein rats in the latest phase of lactation.

\section{Methods}

2.1. Animals and Diets. The experiment was formally approved by the institutional ethical committee and followed the COBEA guidelines (Brazilian College of Experimental Animal) adopted by Mato Grosso Federal University (UFMT) [16]. Female Wistar rats (90d) were supplied by the animal central care facility of the UFMT, Cuiaba, Brazil. Mating was performed by housing females with males overnight and pregnancy was confirmed by the presence of sperm in vaginal smears. Virgin and pregnant females were separated and maintained from the first day of pregnancy until the 18th day of lactation with isocaloric diets containing $60 \mathrm{~g}$ protein $/ \mathrm{kg}$ (low-protein diet) or $170 \mathrm{~g}$ protein $/ \mathrm{kg}$ (control diet) as described by Ferreira et al. [15].

Spontaneous delivery took place the 22nd day of pregnancy and after which, at 3 days of age, large litters were reduced to eight pups, ensuring a standard litter size per mother, that were weighed three times a week until the end of experimental period. Lactating and non-lactating rats were divided in four groups and evaluated from the first day until the 18th day of lactation, as follows: control non-lactating $(\mathrm{CNL})$ and lactating $(\mathrm{CL})$, low-protein nonlactating (LPNL), and lactating (LPL), with free access to food and water. The control non-lactating and low-protein non-lactating groups were formed by virgin rats. They were kept under standard lighting conditions ( $12 \mathrm{~h}$ light/dark cycle) at a $24 \pm 1^{\circ} \mathrm{C}$ of temperature. Food intake was evaluated at same times of animal weighting.

Milk production in each group was estimated as described by do Carmo et al. [17] as the difference between weights of the offspring soon after suckling and after $24 \mathrm{~h}$ fasting, at the 16th day of lactation. The differences were taken as the amount of milk suckled from the dams.

2.2. Sample Collection and Analyses. At the end of the experimental period (18th day of lactation) the rats were euthanized with $\mathrm{CO}_{2}$ and the blood was collected after decapitation. Serum was obtained by centrifugation and aliquots were stored at $-80^{\circ} \mathrm{C}$. Serum glucose was measured by the glucose oxidase method (Accu-chek, Roche Diagnostics, Germany), total protein by the biuret modified method [18] and albumin by the green bromocresol method [19]. Serum hormone concentrations were analyzed by ELISA assay cross-reaction kits for rats: insulin (Linco Research, USA), prolactin (Alpco Diagnostics, USA), leptin (Antigenix American Inc., USA), and glucagon (Wako, USA).

Gonadal white adipose tissue (GON), liver, mammary gland (MAG), and carcass (CARC) were quickly removed after euthanasia for fresh weight determination $(\mathrm{g})$ and kept at $-80^{\circ} \mathrm{C}$ until its use for dosages. Liver fragments were excised to determination of glycogen content [20]. The fat content in the tissues was measured according to Folch method [21], and values were expressed as mg of lipid/100 mg of tissue. Carcasses lipid was analyzed as described by Oller de Nascimento and Williamson [22] and values were expressed as $\mathrm{mg}$ of lipid/100 $\mathrm{mg}$ of carcass.

2.3. Measurements of Enzymes Activities. Hepatic enzymes activities were measured by the following methods: glucose6-phosphate dehydrogenase (G6PDH) was assayed as described by Lee [23], malic enzyme (ME) by the method of Ochoa [24] modified by Hsu and Lardy [25]. Both assays were performed by measuring the rate of formation of NADP. ATP-citrate lyase (ATP-cit) was assayed as described by Srere [26], measuring the rate of oxidation of NADH. Absorbance was taken each $30 \mathrm{~s}$ at $340 \mathrm{~nm}$. Enzymes activities were expressed as nmol NADH $\cdot \mathrm{mg}$ of protein ${ }^{-1} \cdot \mathrm{min}^{-1}$. Protein concentration was determined as described by Lowry [27].

2.4. Statistical Analyses. Results were expressed as mean \pm SEM for the number of rats indicated. Levene's test for homogeneity of variances was initially used to determine whether data complied with the assumptions of parametric analysis of variance. When necessary, data were logtransformed to correct for variance in heterogeneity or nonnormality. All data were subsequently analyzed by twoway ANOVA (nutritional status and physiologic status) followed by Tukey-HSD test for individual differences among 
TABLE 1: Absolute (g) and relative (g/100 g body mass) food intake, protein intake, initial and final body mass of non-lactating and lactating rats maintained with control (CNL and CL) or low-protein (LPNL and LPL) diets.

\begin{tabular}{|c|c|c|c|c|}
\hline & \multicolumn{4}{|c|}{ GROUPS } \\
\hline & CNL & CL & LPNL & LPL \\
\hline Absolute food intake & $293 \pm 18^{b}$ & $573 \pm 26^{\mathrm{a}}$ & $276 \pm 11^{\mathrm{b}}$ & $308 \pm 9^{\mathrm{b}}$ \\
\hline Relative food intake & $92 \pm 1^{c}$ & $100 \pm 1^{\mathrm{b}}$ & $94 \pm 1^{\mathrm{c}}$ & $116 \pm 4^{\mathrm{a}}$ \\
\hline Absolute protein intake & $50 \pm 8^{\mathrm{b}}$ & $97 \pm 4^{\mathrm{a}}$ & $16.5 \pm 0.6^{\mathrm{c}}$ & $19.3 \pm 0.9^{\circ}$ \\
\hline Relative protein intake & $15.5 \pm 0.1^{\mathrm{b}}$ & $17.0 \pm 0.2^{\mathrm{a}}$ & $5.60 \pm 0.04^{\mathrm{d}}$ & $7.0 \pm 0.2^{c}$ \\
\hline Initial body mass & $268 \pm 4$ & $404 \pm 10^{*}$ & $255 \pm 2^{\#}$ & $362 \pm 16^{* \#}$ \\
\hline Final body mass & $300 \pm 7^{b}$ & $330 \pm 8^{c}$ & $287 \pm 5^{\mathrm{b}}$ & $249 \pm 10^{\mathrm{a}}$ \\
\hline
\end{tabular}

CNL, CL, LPNL groups $=7$; LPL group $=8$ rats. Values are means \pm SEM.

${ }^{*}$ Statistical difference related to non-lactating rats (Two-Way ANOVA; $P<.05$ ).

${ }^{\#}$ Statistical difference related to control rats (Two-Way ANOVA; $P<.05$ ).

Different letters indicate statistical differences (Tukey HSD test; $P<.05$ ).

TABLE 2: Serum concentration of total protein, albumin, glucose, insulin, glucagon, leptin, prolactin, insulin/glucose, and insulin/glucagon ratios of non-lactating and lactating rats fed control (CNL and CL) or low-protein (LPNL and LPL) diets.

\begin{tabular}{|c|c|c|c|c|}
\hline & \multicolumn{4}{|c|}{ GROUPS } \\
\hline & $\mathrm{CNL}$ & $\mathrm{CL}$ & LPNL & LPL \\
\hline Total protein $(\mathrm{g} / \mathrm{dL})$ & $4.9 \pm 0.4^{\mathrm{b}}$ & $5.2 \pm 0.4^{\mathrm{b}}$ & $4.9 \pm 0.6^{\mathrm{b}}$ & $3.4 \pm 0.3^{\mathrm{a}}$ \\
\hline Albumin (g/dL) & $3.1 \pm 0.1$ & $2.7 \pm 0.2$ & $2.2 \pm 0.3^{\#}$ & $1.8 \pm 0.2^{\#}$ \\
\hline Glucose (mg/dL) & $109 \pm 2$ & $108 \pm 6$ & $124 \pm 4^{\#}$ & $112 \pm 4^{\#}$ \\
\hline Insulin (ng/mL) & $3.5 \pm 0.8$ & $1.7 \pm 0.5^{*}$ & $1.8 \pm 0.2^{\#}$ & $0.52 \pm 0.08^{* \#}$ \\
\hline Glucagon (ng/mL) & $1.1 \pm 0.2$ & $0.6 \pm 0.1^{*}$ & $0.6 \pm 0.2^{\#}$ & $0.5 \pm 0.1^{* \#}$ \\
\hline Leptin (ng/mL) & $2.5 \pm 0.7$ & $1.1 \pm 0.2^{*}$ & $3.7 \pm 0.6$ & $1.1 \pm 0.3^{*}$ \\
\hline Prolactin $(\mathrm{ng} / \mathrm{mL})$ & $27 \pm 4^{\mathrm{c}}$ & $130 \pm 4^{\mathrm{a}}$ & $22 \pm 8^{c}$ & $65 \pm 6^{b}$ \\
\hline Insulin/glucose molar ratio & $102 \pm 22$ & $53 \pm 18^{*}$ & $47 \pm 3^{\#}$ & $15 \pm 2^{* \#}$ \\
\hline Insulin/glucagon molar ratio & $1.4 \pm 0.4$ & $1.1 \pm 0.2^{*}$ & $1.5 \pm 0.2$ & $0.5 \pm 0.1^{*}$ \\
\hline
\end{tabular}

CNL, CL, LPNL groups $=7 ;$ LPL group $=8$ rats. Values are means \pm SEM.

${ }^{*}$ Statistical difference related to non-lactating rats (Two-Way ANOVA; $P<.05$ ).

\#Statistical difference related to control rats (Two-Way ANOVA; $P<.05$ ).

Different letters indicate statistical differences (Tukey HSD test; $P<.05$ ).

groups. Different superscript letters were employed to mark statistical differences. Student's $t$ test was used to compare two groups. $P<.05$ indicated statistical significance. All statistical comparisons were done using the Statistics Software Package (Statsoft, Tulsa, OK, USA).

\section{Results}

Absolute food intake was similar in low-protein lactating dams compared to controls, but the increases were found in both LPL and LPNL when normalizing it by percentage of body mass. Protein intake was reduced in absolute and relative terms in low-protein groups. By the end of experimental period, LPL group significantly reduced the final body mass (Table 1).

Serum protein concentration was significantly lower in LPL, but albumin levels were reduced in both low-protein groups (LPNL and LPL). In an opposite way, serum glucose values of these rats were higher than the controls (Table 2).

Lactation lowered serum insulin and glucagon levels, markedly in LPL dams, being that we found insulinemia 3.5 times lower than in CL. On the other hand, low-protein diet reduced both insulin and glucagon levels when compared to controls. And, although the lowest ratios of insulin/glucose and insulin/glucagon in lactating groups (LPL, CL) the lowprotein diet reduced the insulin/glucose ratio. Lactation induced rise in serum prolactin levels in both LPL and CL, but it was impaired in low-protein dams and, a fall in serum leptin levels was observed in both control and low-protein lactating dams (Table 2).

By this period, LPL dams lost some relative mass of mammary glands, whereas control dams retained their MAG weights. Lipid content also reduced in MAG of control and low-protein rats (Table 3 ). Daily milk production was decreased in LPL group too, according to Figure 1, with consequent impairment of body mass gain in LPL pups (Figure 2).

Other lipid-providing tissue such as GON was reduced in both lactating groups (LPL and CL) (Table 3 ).

Table 4 shows the liver parameters analyzed. In lactating rats, the mass ( $\mathrm{g}$ ) and the lipid content (\%) were increased in this tissue as compared to non-lactating ones (in absolute 
TABLE 3: Relative mass (g/100g body mass) and lipid content ( $\mathrm{g}$ ) of tissues and carcass of non-lactating and lactating rats fed a control (CNL and CL) or low-protein (LPNL and LPL) diets.

\begin{tabular}{|c|c|c|c|c|}
\hline & \multicolumn{4}{|c|}{ GROUPS } \\
\hline & $\mathrm{CNL}$ & $\mathrm{CL}$ & LPNL & LPL \\
\hline & \multicolumn{4}{|c|}{ Relative mass of tissues ( $\mathrm{g} / 100 \mathrm{~g}$ ) } \\
\hline MAG & $2.0 \pm 0.2^{c}$ & $3.2 \pm 0.2^{\mathrm{a}}$ & $3.0 \pm 0.3^{b}$ & $2.5 \pm 0.2^{c}$ \\
\hline GON & $5.4 \pm 0.3$ & $4.2 \pm 0.3^{*}$ & $6.2 \pm 0.5$ & $4.4 \pm 0.4^{*}$ \\
\hline \multirow[t]{2}{*}{ CARC } & $72.6 \pm 0.8$ & $69.2 \pm 0.5^{*}$ & $72.4 \pm 0.8$ & $71.4 \pm 0.5^{*}$ \\
\hline & \multicolumn{4}{|c|}{ Lipid content (g/100 g) } \\
\hline MAG & $68 \pm 2$ & $21 \pm 5.0^{*}$ & $71 \pm 1.0$ & $32 \pm 7.0^{*}$ \\
\hline GON & $79.2 \pm 3.5$ & $78 \pm 2.0^{*}$ & $79.6 \pm 0.6$ & $76 \pm 1.0^{*}$ \\
\hline CARC & $9.0 \pm 1.0$ & $6.4 \pm 0.7$ & $8.2 \pm 0.9$ & $6.3 \pm 1.0$ \\
\hline
\end{tabular}

CNL, CL, LPNL groups $=7$; LPL group $=8$ rats. Values are means \pm SEM.

* Statistical difference related to non-lactating rats (Two-Way ANOVA; $P<.05$ ).

\#Statistical difference related to control rats (Two-Way ANOVA; $P<.05$ ).

Different letters indicate statistical differences (Tukey HSD test; $P<.05$ ).

TABLE 4: Liver mass, glycogen content, lipid content, lipid/glycogen ratio, and lipogenic enzymes activities $\left(\mathrm{nmol} \cdot \mathrm{mg} \mathrm{of} \mathrm{protein}^{-1} \cdot \mathrm{min}^{-1}\right)$ of non-lactating and lactating rats fed a control (CNL and CL) or low-protein (LPNL and LPL) diets.

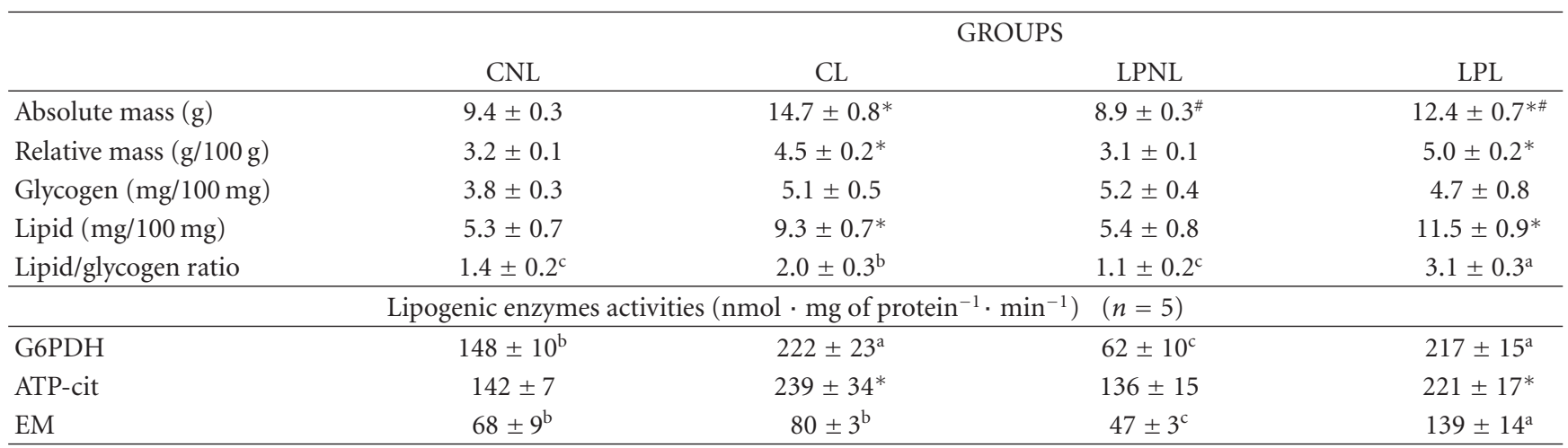

CNL, CL, LPNL groups $=7$; LPL group $=8$ rats. Lipogenic enzymes activities were obtained from 5 animals. Values are means \pm SEM.

* Statistical difference related to non-lactating rats (Two-Way ANOVA; $P<.05$ ).

\#Statistical difference related to control rats (Two-Way ANOVA; $P<.05$ ).

Different letters indicate statistical differences (Tukey HSD test; $P<.05$ ).

and relative values), although the absolute mass had decrease in both low-protein groups. Glycogen content did not differ between groups, but the lipid-to-glycogen ratio in the liver elevated in LPL rats. Following these parameters, the liver lipogenic enzymes G6PDH and ATP-cit activities were markedly increased by lactation, and in low-protein dams (LPL) higher levels of malic enzyme activity was observed.

\section{Discussion}

Despite the highest initial body mass and relative food intake observed, the lactating low-protein dams reached the lowest values of final body mass and decrease of serum albumin concentration was observed in low-protein animals. This is a well-described consequence of scarce nitrogen stores for milk-protein synthesis in low-protein malnourishment $[5,8$, 28]. The lactation-induced loss of mammary gland weight in protein-restricted dams (with lowered milk production) then argues for a general modification of nutrient metabolism, where milk synthesis is impaired at the glandular level.

According to Dewey [28], a suitable protein supply in maternal diet is necessary to enhance milk production and allows a positive increase in milk's protein balance. Zambrano et al. [29] described that offspring whose mothers have restricted protein diet during lactation weighed less than those whose mothers were on the control diet. Additionally, Park et al. [14] indicated that poor nutrition in early life, especially protein restriction, causes long-lasting changes in mitochondria, and this change is more evident in the liver and skeletal muscle, that may contribute to the development of insulin resistance in later life. Choi et al. [13] demonstrated the occurrence of structural changes in the liver and, important changes in lipid metabolism in rats submitted to $25 \%$ of food restriction.

Serum prolactin was $70 \%$ lower in low-protein dams, endowing the low MAG weight observed and putting the 


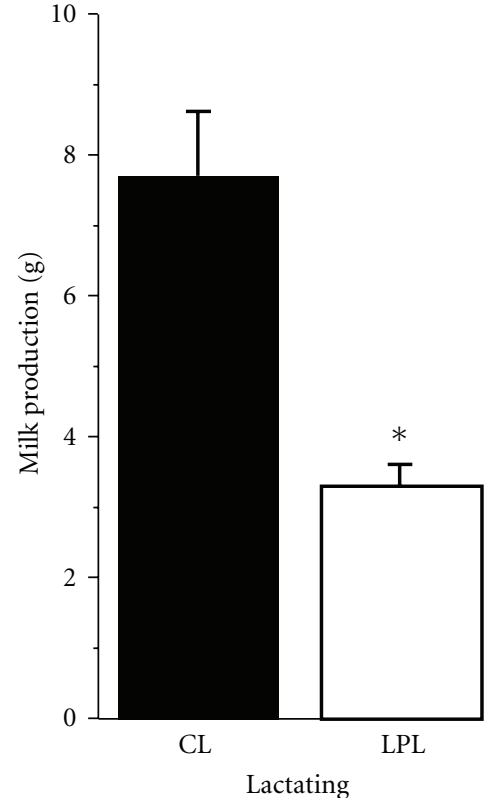

FIgURE 1: Daily milk production by control (CL) and lowprotein (LPL) lactating. Bars are means \pm SEM, $n=7$ mothers. * Statistically different from control lactating (Student's $t$-test; $P<$ $.05)$.

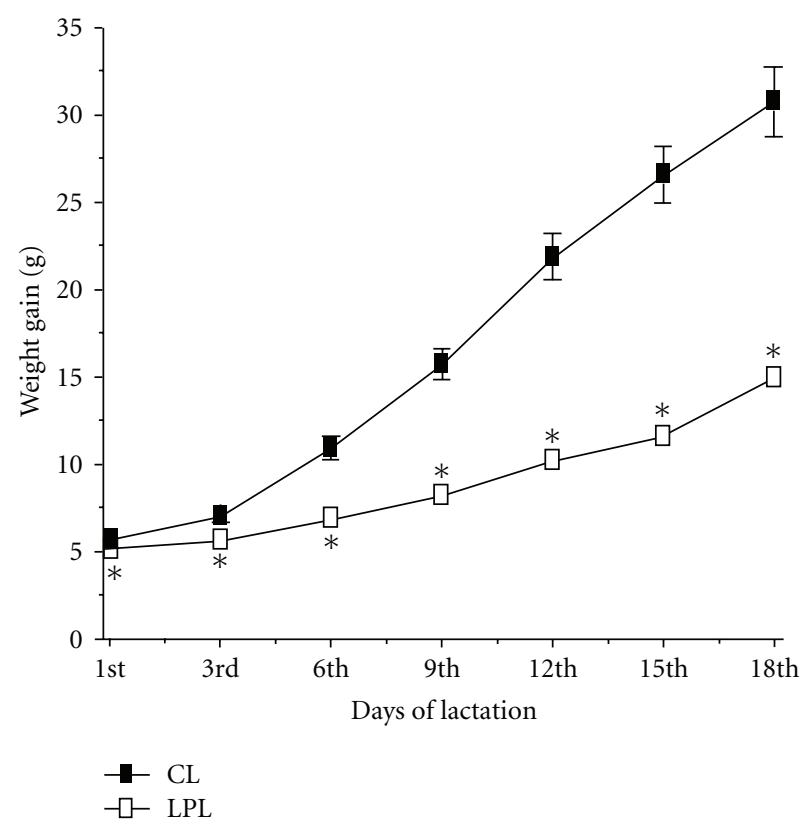

Figure 2: Weight gain of pups weaned by control (CL) and lowprotein (LPL) lactating. Values are means \pm SEM; $n=7$. ${ }^{*} P<.05$ relative to CL (Student's $t$-test). Pups of control and low-protein mothers were weighed each 3 days after birth until the 18th day of lactation.

impaired milk production on a pituitary/hormonal level. Recent studies demonstrated that the actions of prolactin are not confined to the mammary gland [30], but contributes to maternal leptin resistance, increased food intake, and maternal behaviors immediately after parturition [30, 31].

Lactation half end is characterized by decreased insulinemia and leptinemia. These low insulin and leptin levels in lactating rats are associated to catabolic processes releasing fatty acids from the adipose tissue, towards to the liver. In lactating low-protein dams the insulinemia reduced in 2-thirds as compared to control lactating, prompting to a higher release of fatty acids. According to Sipols et al. [32], low insulin and leptin concentrations can lead to hyperphagia, which could have contributed to the elevation of food intake verified in both lactating groups $[6,33]$.

We found increased serum glucose levels and reduced insulinemia in low-protein groups, especially in lactating dams. Moreover, in low-protein lactating rats the insulin/glucagon ratio was $46 \%$ lower than in control. As described, a higher fatty acid mobilization from depots is usually observed during lactation, to provide fatty acids towards the mammary gland and other tissues $[5,6]$. The lactating groups exhibited a reduction in the mass and lipid content of gonadal adipose tissue on the 18th day of lactation. In our model, since this lipid mobilization did not result in increased milk production, a first place for lipid deposition is the liver.

Both lactating groups exhibited increased mass and lipid content in the liver. Accumulation of fats in the liver during early, but not in late lactation, is usually verified and seldom impairs its functions [12]. The stored lipid-to-glycogen ratio in low-protein lactating group was, however, very higher $(3: 1)$, and even in control lactating group this parameter was in the limit $(2: 1)$. Previous studies had shown that when this ratio exceeds about $2: 1$, pathological problems begin to develop [2]. The reason for the pathological effects of high levels of TAG in liver is unclear, but it can relate to prolonged elevation of nonesterified fatty acids (NEFA) levels and/or their CoA esters in the cell [34]. Because lipid homeostasis is mainly dependent on the liver, the underlying lipid deregulation in lactating nutritional restricted rats would be mediated, at least in part, through alterations of liver structure $[13,14]$.

Additionally, lactation strongly increased the liver lipogenic enzymes in lactating dams, as compared to nonlactating females, especially malic enzyme that elevated only in low-protein dams. Hormonal and nutritional conditions that modify liver lipogenic enzymes activities are described [35, 36], with insulin being stimulatory and glucagon a depressor [37]. Previous studies showed that a high carbohydrate diet stimulates the expression of liver lipogenic enzymes [38] and contributes to elevate plasma TAG levels [39]. In our model, diet protein was replaced by carbohydrate for keeping isocaloric diets. This model did not increase lipogenic enzymes in non-lactating females and even decreased malic enzyme activity both in low-protein nonlactating, as in control lactating. This pattern of alterations is very likely related to the insulin to glucagon ratios observed, reinforcing the hormonal control of liver lipogenesis.

Previous works with this model of protein deficiency in pregnancy and lactation have stated permanent changes in expression of liver enzymes involved in glucose homeostasis 
$[40,41]$, increases of liver insulin sensitivity [26, 41] and reduction of glucose tolerance [42]. Such studies explored the offspring physiology but not the dams.

In this study we observed that low-protein diet during lactation decreased the development of mammary gland and prolactin secretion which resulted in lower milk production and impaired pups growth. Lactation enhanced liver mass, lipid content and lipogenic enzymes activities. Moreover, this diet enhanced the store of lipid to glycogen ratio and suggests a higher risk of fatty liver development.

\section{Abbreviations}

TAG: Triacylglycerol

NEFA: Nonesterified fatty acid

MAG: Mammary gland

VLDL: Very low density lipoproteins

CNL: Control non-lactating group

CL: $\quad$ Lactating group

LPNL: Low-protein non-lactating group

LPL: Lactating group

GON: Gonadal white adipose tissue

CARC: Carcass

G6PDH: Glucose-6-phosphate dehydrogenase enzyme

ME: $\quad$ Malic enzyme

ATP-cit: ATP-citrate lyase enzyme

ELISA: Enzyme-linked immunosorbent assay

ANOVA: Analysis of variance.

\section{Acknowledgments}

The authors thank Celso Roberto Afonso, for technical assistance. This work was supported by the Brazilian Foundations FAPEMAT (Grant no. 175/07). T. S. S. Gonçalves was the recipient of a FAPEMAT fellowship. The authors disclosed having no conflict of interests.

\section{References}

[1] R. G. Vernon, "Lipid metabolism during lactation: a review of adipose tissue-liver interactions and the development of fatty liver," Journal of Dairy Research, vol. 72, no. 4, pp. 460-469, 2005.

[2] J. K. Drackley, T. R. Overton, and G. N. Douglas, "Adaptations of glucose and long-chain fatty acid metabolism in liver of dairy cows during periparturient period," Journal of Dairy Science, vol. 84, pp. E100-E12, 2001.

[3] G. Boden and G. I. Shulman, "Free fatty acids in obesity and type 2 diabetes: defining their role in the development of insulin resistance and $\beta$-cell dysfunction," European Journal of Clinical Investigation, vol. 32, no. 3, pp. 14-23, 2002.

[4] D. G. Fong, V. Nehra, K. D. Lindor, and A. L. Buchman, "Metabolic and nutritional considerations in nonalcoholic fatty liver," Hepatology, vol. 32, no. 1, pp. 3-10, 2000.

[5] D. E. Bauman, "Regulation of nutrient partitioning during lactation: homeostasis and homeorhesis revisited," in Ruminant Physiology: Digestion, Metabolism, Growth and Reproduction, pp. 311-328, 2000.
[6] R. G. Vernon, R. G. P. Denis, A. Sorensen, and G. Williams, "Leptin and the adaptations of lactation in rodents and ruminants," Hormone and Metabolic Research, vol. 34, no. 1112, pp. 678-685, 2002.

[7] R. G. Vernon and C. M. Pond, "Adaptations of maternal adipose tissue to lactation," Journal of Mammary Gland Biology and Neoplasia, vol. 2, no. 3, pp. 231-241, 1997.

[8] D. H. Williamson, "Integration of metabolism in tissues of the lactating rat," FEBS Letters, vol. 117, pp. K93-K105, 1980.

[9] H. M. Dann, G. N. Douglas, T. R. Overton, and J. K. Drackley, "Carnitine palmitoyltransferase activity in liver of periparturient dairy cows," Journal of Dairy Science, vol. 83, supplement 1, p. 251, 2000.

[10] A. M. van den Top, T. Wensing, M. J. Geelen, G. H. Wentink, A. T. van't Klooster, and A. C. Beynen, "Time trends of plasma lipids and enzymes synthesizing hepatic triacylglycerol during postpartum development of fatty liver in dairy cows," Journal of Dairy Science, vol. 78, no. 10, pp. 2208-2220, 1995.

[11] V. A. Zammit, "Ketogenesis in the liver of ruminantsadaptations to a challenge," Journal of Agricultural Science, vol. 115, pp. 155-162, 1990.

[12] R. G. Vernon, "Adipose tissue: an expanding role in the regulation of energy metabolism," in Progress in Research on Energy and Protein Metabolism, pp. 451-464, 2003.

[13] G. Y. Choi, D. N. Tosh, A. Garg, R. Mansano, M. G. Ross, and M. Desai, "Gender-specific programmed hepatic lipid dysregulation in intrauterine growth-restricted offspring," American Journal of Obstetrics and Gynecology, vol. 196, no. 5, pp. 477.e1-477.e7, 2007.

[14] K. S. Park, S. K. Kim, M. S. Kim et al., "Fetal and early postnatal protein malnutrition cause long-term changes in rat liver and muscle mitochondria," Journal of Nutrition, vol. 133, no. 10, pp. 3085-3090, 2003.

[15] C. L. P. Ferreira, G. M. Macêdo, M. Q. Latorraca et al., "Serum leptin and insulin levels in lactating protein-restricted rats: implications for energy balance," British Journal of Nutrition, vol. 97, no. 1, pp. 27-34, 2007.

[16] Comissão de Ensino do Colégio Brasileiro de Experimentação Animal (COBEA), Manual para Técnicos em Laboratórios, 2nd edition, 1996.

[17] M. G. T. do Carmo, C. M. O. do Nascimento, A. Martin, and E. Herrera, "Ethanol intake during lactation impairs milk production in rats and affects growth and metabolism of suckling pups," Alcohol, vol. 18, no. 1, pp. 71-76, 1999.

[18] W. Q. Wolfson, C. Cohn, F. Calvary, and F. Ichiba, "Studies in serum proteins 5 . A rapid procedure for the estimation of total protein, true albumin, total globulin, alpha globulin, and gamma globulin in $1.0 \mathrm{ml}$ of serum," American Journal of Clinical Pathology, vol. 18, pp. 723-730, 1948.

[19] B. T. Doumas, W. Ard Watson, and H. G. Biggs, "Albumin standards and the measurement of serum albumin with bromcresol green," Clinica Chimica Acta, vol. 31, no. 1, pp. 8796, 1971.

[20] B. Sjögren, W. A. Koning, H. Holmgeen, and E. J. Möllersöm, "Betrag zur Kennynies der leberrthytlmik (glycogen, phosphor und calcium in des kaninchenleber)," Pflüger's Archiv für die Gesamte Physiologie, vol. 240, pp. 427-436, 1938.

[21] J. Folch, M. Lees, and G. H. Sloane-Stanley, "A simple method for the isolation and purification of total lipides from animal tissues," The Journal of Biological Chemistry, vol. 226, no. 1, pp. 497-509, 1957. 
[22] C. M. Oller do Nascimento and D. H. Williamson, "Tissuespecific effects of starvation and refeeding on the disposal of oral $\left[1-{ }^{14} \mathrm{C}\right]$ triolein in the rat during lactation and on removal of litter," Biochemical Journal, vol. 254, no. 2, pp. 539-546, 1988.

[23] C. Y. Lee, "Glucose-6-phosphate dehydrogenase from mouse," Methods in Enzymology, vol. 89, pp. 252-257, 1982.

[24] S. Ochoa, "Malic enzyme," Methods in Enzymology, vol. 1, pp. 739-753, 1955.

[25] R. Y. Hsu and H. A. Lardy, "Malic enzyme," Methods in Enzymology, vol. 13, p. 230, 1969.

[26] P. A. Srere, "The citrate cleavage enzyme. I. Distribution and purification," The Journal of Biological Chemistry, vol. 234, pp. 2544-2547, 1959.

[27] O H. Lowry, "Protein measurement with of the folin phenol reagent," The Journal of Biological Chemistry, vol. 193, pp. 265$268,1951$.

[28] K. G. Dewey, "Energy and protein requirements duirng lactation," Annual Review of Nutrition, vol. 17, pp. 19-36, 1997.

[29] E. Zambrano, C. J. Bautista, M. Deás et al., "A low maternal protein diet during pregnancy and lactation has sex- and window of exposure-specific effects on offspring growth and food intake, glucose metabolism and serum leptin in the rat," Journal of Physiology, vol. 571, no. 1, pp. 221-230, 2006.

[30] N. Ben-Jonathan, E. R. Hugo, T. D. Brandebourg, and C. R. LaPensee, "Focus on prolactin as a metabolic hormone," Trends in Endocrinology and Metabolism, vol. 17, no. 3, pp. 110-116, 2006.

[31] D. R. Grattan, F. J. Steyn, I. C. Kokay, G. M. Anderson, and S. J. Bunn, "Pregnancy-induced adaptation in the neuroendocrine control of prolactin secretion," Journal of Neuroendocrinology, vol. 20, no. 4, pp. 497-507, 2008.

[32] A. J. Sipols, D. G. Baskin, and M. W. Schwartz, "Effect of intracerebroventricular insulin infusion on diabetic hyperphagia and hypothalamic neuropeptide gene expression," Diabetes, vol. 44, no. 2, pp. 147-151, 1995.

[33] R. G. P. Denis, C. Bing, S. Brocklehurst, J. A. Harrold, R. G. Vernon, and G. Williams, "Diurnal changes in hypothalamic neuropeptide and SOCS-3 expression: effects of lactation and relationship with serum leptin and food intake," Journal of Endocrinology, vol. 183, no. 1, pp. 173-181, 2004.

[34] D. A. K. Roncari and W. K. Murthy, "Lipogenesis and cholesterogenesis de novo in liver and adipose tissue," The Journal of Biological Chemistry, vol. 250, pp. 4134-4138, 1975.

[35] D. R. Romsos and G. A. Leveille, "Effect of diet on activity of enzymes involved in fatty acid and cholesterol synthesis," Advances in Lipid Research, vol. 12, no. 0, pp. 97-146, 1974.

[36] L. A. Witters, D. Moriarity, and D. B. Martin, "Microsomal acetyl-CoA carboxylase: evidence for association of enzyme polymer with liver microsomes," The Journal of Biological Chemistry, vol. 254, pp. 6644-6649, 1979.

[37] N. Iritani, N. Nishimoto, A. Katsurada, and H. Fukuda, "Regulation of hepatic lipogenic enzyme gene expression by diet quantity in rats fed a fat-free, high carbohydrate diet," Journal of Nutrition, vol. 122, no. 1, pp. 28-36, 1992.

[38] D. B. Jump, S. D. Clarke, A. Thelen, and M. Liimatta, "Coordinate regulation of glycolytic and lipogenic gene expression by polyunsaturated fatty acids," Journal of Lipid Research, vol. 35, no. 6, pp. 1076-1084, 1994.

[39] S. Kersten, J. Seydoux, J. M. Peters, F. J. Gonzalez, B. Desvergne, and W. Wahli, "Peroxisome proliferator-activated receptor $\alpha$ mediates the adaptive response to fasting," Journal of Clinical Investigation, vol. 103, no. 11, pp. 1489-1498, 1999.
[40] M. Desai, C. D. Byrne, J. Zhang, C. J. Petry, A. Lucas, and C. N. Hales, "Programming of hepatic insulin-sensitive enzymes in offspring of rat dams fed a protein-restricted diet," American Journal of Physiology, vol. 272, no. 5, pp. G1083-G1090, 1997.

[41] S. E. Ozanne, G. D. Smith, J. Tikerpae, and C. N. Hales, "Altered regulation of hepatic glucose output in the male offspring of protein-malnourished rat dams," American Journal of Physiology, vol. 270, no. 4, pp. E559-E564, 1996.

[42] M. Desai, C. D. Byrne, K. Meeran, N. D. Martenz, S. R. Bloom, and C. N. Hales, "Regulation of hepatic enzymes and insulin levels in offspring of rat dams fed a reduced-protein diet," American Journal of Physiology, vol. 273, no. 4, pp. G899G904, 1997. 




The Scientific World Journal
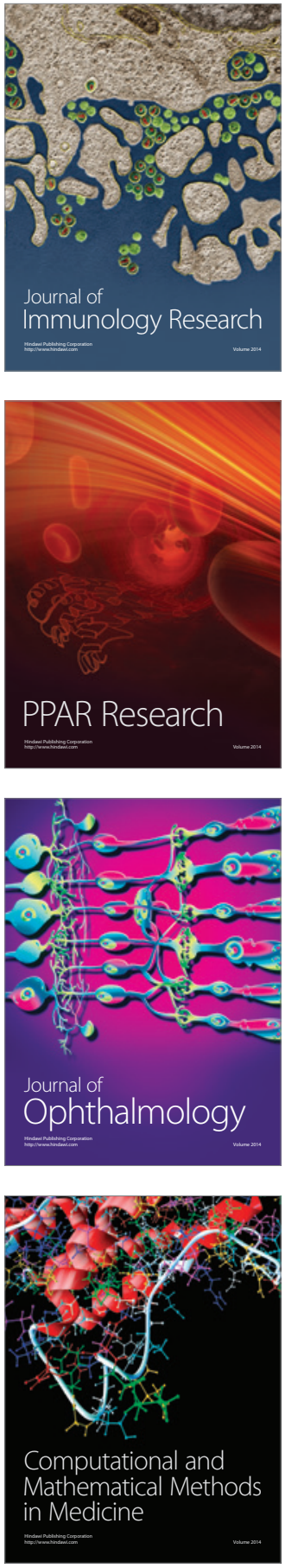

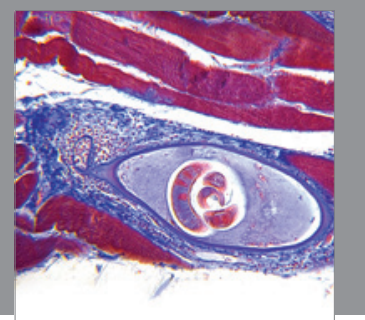

Gastroenterology

Research and Practice
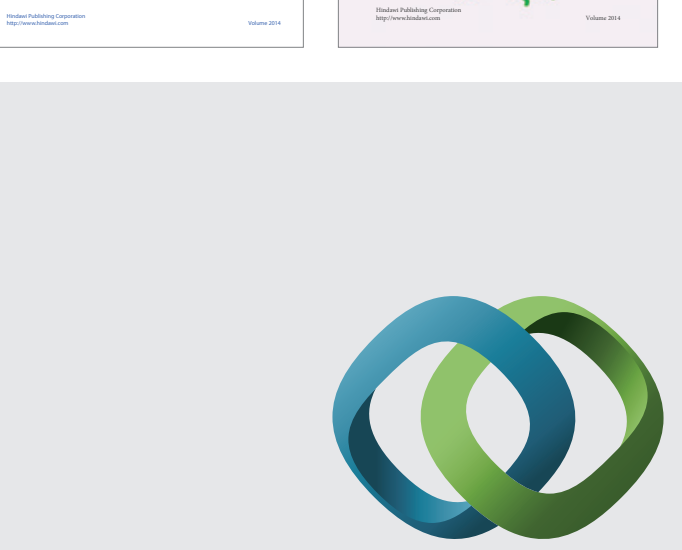

\section{Hindawi}

Submit your manuscripts at

http://www.hindawi.com
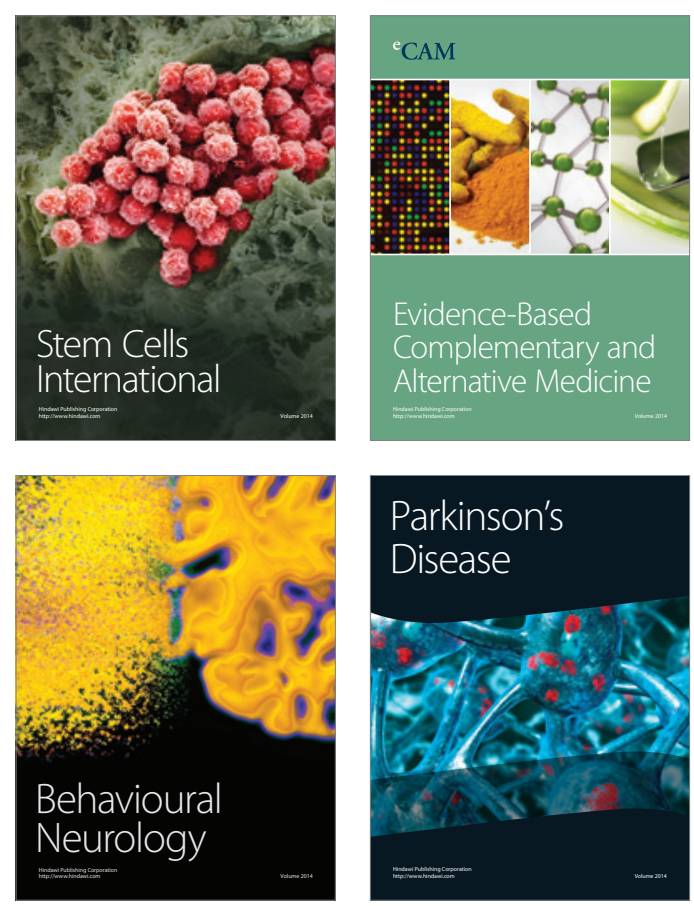

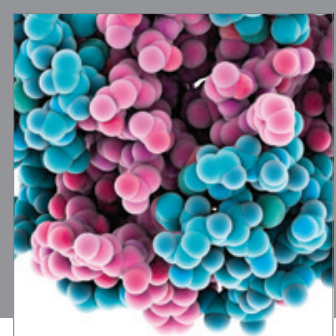

Journal of
Diabetes Research

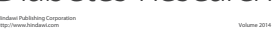

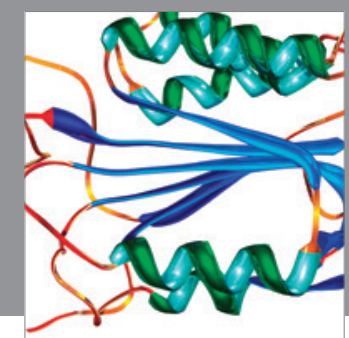

Disease Markers
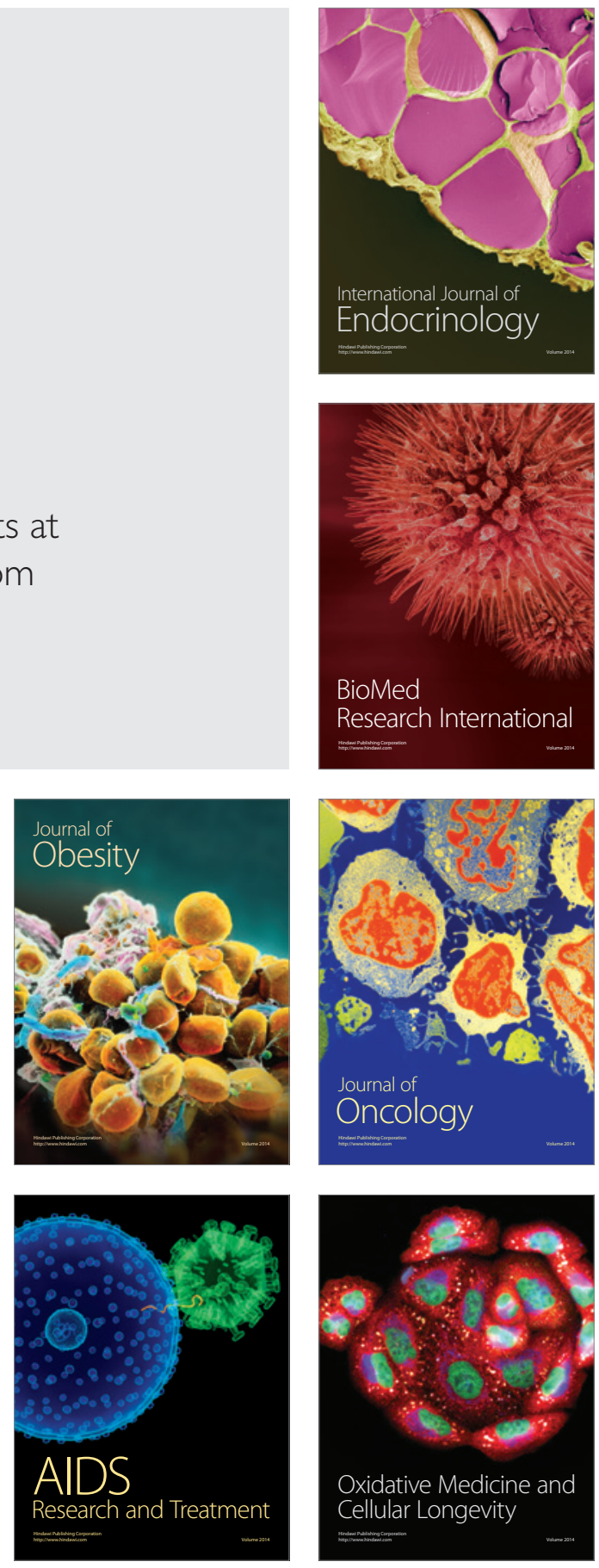